\title{
Assessing the care of children under one year old in Primary Health Care
}

\author{
Maria Cândida de Carvalho Furtado ${ }^{1}$ \\ Janaina Carvalho Braz ${ }^{2}$ \\ Juliana Coelho Pina ${ }^{3}$ \\ Débora Falleiros de Mello ${ }^{4}$ \\ Regina Aparecida Garcia de Lima ${ }^{5}$
}

\begin{abstract}
Objective: to analyze the presence and extent of Primary Health Care attributes and the strength of affiliation of children under one year old in a Family Health Unit. Method: cross-sectional, descriptive study conducted between October 25, 2010 and May 14, 2011 with 44 mothers, using the Primary Care Assessment Tool to collect data. Data were analyzed by calculating the Essential Primary Health Care and General Primary Health Care scores. Results: mothers recognized and experienced aspects of accessibility, comprehensive care and coordination of care, as well as community guidance, marked by a concern and involvement on the part of the health team in the children's care, their families and community. Conclusion: The Primary Health Care team makes efforts to approach the community and meet their health needs, seeking instruments that aid the promotion of qualified care to children.
\end{abstract}

Descriptors: Health Evaluation; Comprehensive Health Care; Primary Health Care; Child Care.

\footnotetext{
${ }^{1}$ PhD, Professor, Escola de Enfermagem de Ribeirão Preto, Universidade de São Paulo, WHO Collaborating Centre for Nursing Research Development, SP, Ribeirão Preto, SP, Brazil.

2 Doctoral Student, Escola de Enfermagem de Ribeirão Preto, Universidade de São Paulo, WHO Collaborating Centre for Nursing Research Development, SP, Ribeirão Preto, SP, Brazil.

${ }^{3}$ RN and Doctoral Student, Escola de Enfermagem de Ribeirão Preto, Universidade de São Paulo, WHO Collaborating Centre for Nursing Research Development, SP, Ribeirão Preto, SP, Brazil.

${ }^{4} \mathrm{PhD}$, Associate Professor, Escola de Enfermagem de Ribeirão Preto, Universidade de São Paulo, Who Collaborating Centre for Nursing Research Development, SP, Ribeirão Preto, SP, Brazil.

${ }^{5}$ PhD, Full Professor, Escola de Enfermagem de Ribeirão Preto, Universidade de São Paulo, WHO Collaborating Centre for Nursing Research Development, SP, Ribeirão Preto, SP, Brazil.
} 


\section{Introduction}

Brazilian public policies have sought to extend the approach to care beyond the biomedical model, which is based on disease and its treatment. Official documents of the Brazilian Ministry of Health (BMH), concerning child health care, consolidate these policies in order to assist children in their needs.

The commitment is to provide comprehensive care, developing actions to prevent disease and giving assistance in order to reduce child mortality and offering quality of life for children, so they can develop their full potential(1-2). Therefore, BMH documents seek to support the organization of care delivery to the infant population and, at the same time, enable health services managers and health professionals to identify priority actions for childhood health. Guidelines for the identification of comprehensive care are proposed based on proper functioning of child health services at the local level in order to provide more satisfactory outcomes to this population.

A child is considered as a whole in its multiple relationships, family is valued, as well as the context in which the child lives. Principles such as access to health services and comprehensive care are highlighted with different levels of care. Facilitating access and promoting child health, including the development of actions for disease prevention and health care when there are complications, can improve child healthcare and, consequently, the quality of life of children.

The assessment of health programs and services has come to have great importance and relevance due to the view that the organization and management of care provided may be viewed differently, particularly in regard to the care provided to users ${ }^{(3-4)}$.

The Brazilian Ministry of Health (BMH) is also concerned with this assessment, especially focused on primary care. The Department of Primary Care and Monitoring and Assessment Coordination of BHM considers this kind of assessment to be necessary as well as complex, additionally requiring careful and consistent investment ${ }^{(5)}$. The assessment also has prominence as a component of health management, recognizing several initiatives designed for the implementation of assessment in the diverse dimensions of the Brazilian Health System ${ }^{(5)}$.

The assessment has the basic purpose of supporting decision-making processes within the health system. Therefore, it should support the identification of problems and the reorientation of actions and services.
It should also address the incorporation of new practices into professionals' routines, as well as measure the impact of implemented actions on the population's health(5)

An official document of the BHM based on child health care principles also highlights the importance of systematic and ongoing assessment as a way of monitoring the principles that guide child care ${ }^{(2)}$.

One of the aspects of health assessment is focused on the outcomes of interventions for people's health, represented by responses or changes in patient health status, such as reduced mortality, improvement in quality of life and user satisfaction. Outcomes are related to changes occurring in patient health status and can be attributed to previously provided care(6-7).

This study aimed to analyze the presence and extent of Primary Health Care (PHC) attributes and the strength of user affiliation in the Family Health Unit based on the experiences of mothers with the care provided to children under one year old.

\section{Material and Method}

This is a cross-sectional, descriptive, and exploratory study and the assessment model proposed by Avedis Donabedian ${ }^{(6-7)}$ was used as the theoretical and methodological framework, specifically the process component.

The study was conducted in an interior city, which is located in northeastern State of São Paulo, Brazil, 313 $\mathrm{km}$ from the capital. The region is one of the richest in the State of São Paulo, with a high standard of living, considering income, expenditure and longevity. It has good social indicators, such as health, education and sanitation, and a prime location, with easy access to major interior cities.

It has an estimated population of 605,114 inhabitants in the 2010 census $^{(8)}$. The city stands out in the region and is a major hub for business activities and services. Its economy is based on the agribusiness and industrial sectors and the city is also a university and research center with an emphasis on medical research.

Regarding the health care network, the city has seven private hospitals and seven charitable hospitals. It also has three public hospitals; two of them are linked to the University of São Paulo (USP).

Due to population growth and to improve people's access to health services, the city organized the care delivery into five regions called Health Districts that are defined based on geographic, economic and social 
aspects, various health facilities and other social facilities. Each Health District has a District Health Unit that provides basic health services and medical specialties. The city has a total of 37 health units (32 basic health units and 5 district health units) and 11 Family Health Units.

The Western Health District serves a population of 200,000 inhabitants; it has two "Centros de Saúde Escola" [School Health Centers]* and seven basic health units and five Family Health Units (FHU) that are linked to the University of São Paulo.

The choice of this Health District is appropriate because it was the first one to implement the Family Health Strategy in the city, approximately ten years ago. The FHU that is the setting of this study has the highest number of births among other FHU in this Health District; so, it experiences great demand for care provided to children under one year old.

In 2010, 8,093 children were born in the city, 1,080 belonging to the Western Health District. The five Family Health Units had 101 births and from those, 50 (49.5\%) children belong to the FHU we chose for the study ${ }^{(9)}$.

The period of data collection was from October 25, 2010 to May 14, 2011. Children under one year old who belong to the FHU were identified and included in the research in the first month of data collection. Children who were born in the months subsequent to this survey were not included.

Of the 50 children identified, 44 (88\%) mothers were found at home or in the FHU during medical or nursing appointments; three (6\%) mothers were not found after two home visits on different days and three (6\%) mothers refused to participate because they had health plan and do not use the service offered by the FHU. Mothers who accepted the invitation signed consent forms. A single interview was then held using the Primary Health Care Assessment Tool-Brazil

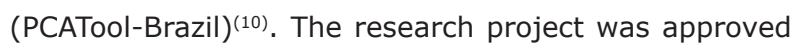
by the Ethics Committee (protocol no 417/10).

The interviews took place at home or after a medical or nursing appointment in the $\mathrm{FHU}$, and it was conducted in a place reserved for that purpose; all mothers had their anonymity preserved.

Data analysis was based on descriptive statistics. The sum of the average values of essential attributes and their sub-dimensions and the average score of the strength of user affiliation with the health service produced the Essential Primary Health Care score. The sum of those essential scores and the average of derivative scores produced the General Primary Health Care score.

PCATool-Brazil was chosen because it allows measuring the presence and extent of the attributes of Primary Health Care services to children and the strength of user affiliation with the health service. It considers essential and derived attributes. By Likert-type answers, the PCATool-Brazil makes the construction of Primary Health Care scores possible with intervals ranging from 1 to 4 for each attribute. The final score of each attribute is the average of the responses of their items, which also range from 1 to 4 , where 4 represents a greater presence and extent of each attribute and 1 refers to the lowest level of presence of the attribute. Values above 3.0 represent a great presence and extent of the analyzed variables ${ }^{(10)}$.

\section{Results}

The strength of affiliation of health service user had a 4.0 score for all mothers, which revealed a strong affiliation with the FHU. Table 1 shows Primary Health Care scores values.

Table 1 - Score values of Primary Health Care attributes. Ribeirão Preto, SP, Brazil, 2011

\begin{tabular}{|c|c|c|c|c|}
\hline Attributes & $<$ & $>$ & Mean & SD \\
\hline First Contact Access - utilization & 2.3 & 4.0 & 3.6 & 0.35 \\
\hline First Contact Access - accessibility & 2.3 & 4.0 & 3.4 & 0.54 \\
\hline Longitudinality & 2.6 & 4.0 & 3.4 & 0.37 \\
\hline Coordination - integration of care & 3.0 & 4.0 & 3.7 & 0.37 \\
\hline Coordination - information system & 3.3 & 4.0 & 3.5 & 0.26 \\
\hline Comprehensive care - available services & 1.6 & 2.8 & 2.3 & 0.31 \\
\hline Comprehensive care - services provided & 1.8 & 4.0 & 3.8 & 0.38 \\
\hline Family Orientation & 2.3 & 4.0 & 3.2 & 0.46 \\
\hline Community Orientation & 2.5 & 4.0 & 3.4 & 0.32 \\
\hline
\end{tabular}

\footnotetext{
* Health Care Units that provide both primary and specialized care. Translator's note.
} 
The final score related to Access - Utilization was above 3.0. This indicates that mothers recognize that they use the FHU to assist their children in routine appointments or for a new health problem.

The attribute Access - Accessibility had a final score above 3.0, i.e. the FHU is easily accessed, and mothers said they have already made their appointment when they go to the FHU; the wait for an appointment to begin does not last more than 30 minutes.

Longitudinality is an attribute that represents child follow-up by the same health professional over a period of time and communication skills between health professional and mother, as well. Final scores were also high; mothers thought that doctors and nurses understand their questions related to their child 's health; they also understand health professionals' responses to their doubts. Interviewees reported enough time to disclose their concerns to health staff members who know their child's clinical history and recognize their child not as a health problem but as a human being. When we asked whether they would move their child's health care to another health facility if it were easy to do so, the mothers responded emphatically that they would not change.

The next attribute presented in Table 1 is related to Coordination, which involves care integration and represents mothers' experiences when their children were referred to a secondary care facility for specific health examinations or appointments with specialists.

Because it is an item that represents an addition to the child care service, only 13 (26\%) mothers reported that their children were referred to another health care service. The score for that attribute was above 3.0, indicating a strong presence of this attribute and a good experience for mothers. Their children were referred to specialist services and the health team from the FHU has always been close to the child, either by having an awareness of the specialist appointment or exams results. To interviewees, this care reveals a great interest on the part of the health team in the quality of care offered to children in specialized services.

Coordination of care represents another subdimension that corresponds to information systems. Those represent documents, records or reports used by the health team in child consultations. The score was above 3.0; mothers responded that they take at least one child document to the consultation; the ones most frequently mentioned were vaccination cards, followed by birth registrations. Mothers emphasize that during their consultation, their children's medical records are always available.

Regarding the Comprehensive care attribute, available services and orientation sessions for mothers or families in order to use health units had the lowest score. The answers indicate the FHU does not have most of the services indicated in the PCATool-Brazil, including an immunization room, counseling and treatment of visual problems, harmful use of drugs or mental health problems, and counseling and HIV test requests.

In contrast to the previous attribute, we found a strong presence and extent of a further subdivision in the Comprehensive care attribute, which refers to services provided during routine child appointments. This item had a score greater than 3.0. Mothers emphasized that in all doctor or nursing appointments, the health team addresses issues such as guidelines to keep a child healthy, food orientation, hygiene, rest, accident prevention and changes in a child's growth and development.

The last two attributes in the PCATool-Brazil are attributes derived from Primary Health Care and they refer to Family and Community Orientation. They pose questions related to the involvement of the health team with every family in the FHU area of coverage and with the community, as well.

Regarding Family Orientation, the score presented was above 3.0. Mothers pointed out that doctors and nurses know their families, their problems and their major health needs.

The last attribute shown in Table 1 refers to Community Orientation, i.e. the monitoring of families in their coverage area by a health team. This item also had a high score, 3.0. Mothers reported receiving home visits from the family health team; most of these visits were by a Community Health Agent, followed by nurses and medical staff. Mothers also believed that the health team wants to know of the health problems in the community.

By performing the sum of the average values of the essential attributes with the average score of the strength of user affiliation to health service, the Primary Health Care Essential Score was produced. Table 2 presents this score as above 3.0 and demonstrates that mothers have experience in caring for their children in the FHU; this reveals not only high presence, but also the great extent of PHC attributes. 
Table 2 - Values of Primary Health Care Essential and General Scores. Ribeirão Preto, SP, Brazil, 2011

\begin{tabular}{lccccc}
\hline & Score & $<$ & $>$ & mean & SD \\
\hline Primary Health Care Essential score & & 2.7 & 3.6 & 3.1 & 0.20 \\
Primary Health Care General score & & 2.5 & 3.7 & 3.0 & 0.30 \\
\hline
\end{tabular}

Table 2 also presents the results of the Primary Health Care General Score, which is represented by the sum of the essential and derivate attributes of all respondents. This study showed a strong presence of such attributes in caring for children in the FHU. This means that mothers recognize and experience issues like Accessibility of health services, Comprehensive care, and Coordination of care, as well as Family and Community orientation with the concern and involvement of all health professionals from the FHU in child care, and their families and community care.

\section{Discussion}

The recognition of the FHU as the health unit of reference for their child was unanimous in the responses of study participants. Mothers attend the FHU for the child's routine appointments, as well as in emergency situations. They experience easy access to the FHU without problems scheduling appointments or having to wait for child consultations.

This finding corroborates the work of an author(11) that addresses the importance of it being the case that each time there is a health need, there must be an entry point, easily accessible and that should also be the first health resource to be searched.

Access can be understood as an opportunity to achieve better health outcomes, enabling people to reach services that should provide the structure needed to promote attention to the first contact between health team and families and not postponing contact in such a way that diagnoses and management of the problem are adversely affected ${ }^{(12)}$. Health care facilities are also expected to offer treatment and an available health team, reception, and the possibility for the user to attend the FHU, involving time and financial resources ${ }^{(13)}$.

According to mothers, most of the time the health professionals who perform child care are the same; they show familiarity with the child and knowledge of the child's medical history and provide clear and accurate information; they also give time for the free expression of the mother's doubts and questions related to the child's care.

This long-term relationship between health professionals and their patients in health care facilities is recognized as Longitudinality of attention. It is achieved when there is a local individual or team who serves as a source of care for a certain period; its essence is the personal relationship over time and it is unrelated to the health problem ${ }^{(11)}$.

In contrast with our results, a study that aimed to identify the therapeutic journey of families seeking care for their child with respiratory disease pointed that the attributes such as access and longitudinality were not found in health services ${ }^{(14)}$.

When the same health professionals remain as providers during children's follow-up in a health facility and provide information to mothers in routine visits, they allow an extension of care. Mothers who attend treatment at a health facility service are looking for interaction with the health team that is responsible for childcare. The dialog presents itself as an important link and works in the construction of a potential space for the gradual achievement of trust, security and the identity of a mother as a caretaker of the child(15).

Despite the fact that referrals to specialist services have been reported by few mothers, there was a significant amount of importance recognized by mothers, regarding the health professional's presence and interest in the process of referring them to such specialist services, as well as in follow-up, exams and their results.

Regarding the information system for the provision of quality care, this study showed that mothers carry some sort of documents for their children to medical appointments. They also recognize that the FHU registration system means the child's records are always available during consultations, which shows the organization of the health service in the recording of follow-up.

In this case, the attribute considered is the Coordination of care, which is presented as essential for other aspects of primary care. Its essence is the availability of information concerning the problems and services previously provided, especially when they are related to current problems ${ }^{(11)}$. It is necessary that health professionals be aware of the patient's health problems, regardless of the context in which they appear, as found in this study. 
The availability of services in the FHU was the attribute of Comprehensive care that received the lowest score, as pointed out earlier, and demonstrates that some services are admittedly not available. On the other hand, the study participants had difficulty or could not answer regarding services such as nutritional supplementation programs, counseling and treatment for drug use, counseling for and requesting an HIV test, which generated a low score and indicated the nonpresence of this attribute.

Comprehensive care demands proper recognition of user health needs, providing resources for their management and resolution(11), such as those identified in the referral of children to specialized care. This is an important mechanism that ensures the adjustment of health service needs. Thus, health professionals have a responsibility to identify health care needs and provide and coordinate services in primary care facilities, referring only the cases that cannot be handled at this place $^{(11)}$.

We uncovered that mothers consider services such as immunization being available at the FHU to be extremely important, since child follow-up is conducted at this location and vaccines are given in another health facility.

Comprehensive care is understood in institutional, intentional and procedural articulation where each health facility vitalizes the flow from individuals and populations' needs(12). It means to learn the user's needs by listening and then to increase the capacity and capability for interventions by health professionals who are concerned with the problems that people demand health services meet ${ }^{(16)}$.

On the other hand, an attribute related to Comprehensive care - services provided - obtained a high score. Almost all mothers recognize that health professionals address important issues about child health during routine appointments.

These findings corroborate a study(15) in which mothers recognize their child follow-up as an important aspect in the monitoring of growth and development: checking weight; evaluating breastfeeding and feeding patterns; preventing diseases; indicating medication use or verifying the need to monitor a child in other health services.

Child follow-up is considered a pediatric area of disease prevention and health promotion. The related goals involve the promotion of child health, disease prevention and family member's education. Health professionals should provide unwavering support to families through preventive guidelines, a comprehensive approach to children's growth and development, in addition to clinical care for any disease situation ${ }^{(17)}$.

We identified health professionals interested and concerned with health needs of each family and the community as well. Through home visits, positively confirmed in all interviews, mothers highlighted the health team as responsible for their individual, family or community health care.

The inclusion of health professionals in the community through home visits not only strengthens bonds, but also enables them to understand the social determinants of health disease process ${ }^{(18)}$. The commitment of health professionals to a population enables a space for each singular individual to be encompassed and heard. This also contributes to restoring the autonomy of people who require health care(18-19). $^{(19)}$

In the context of Primary Health Care, the Family Health Strategy aims to articulate some principles such as universality, equity, comprehensive care, seeking to understand the family and its social environment, creating bonds, commitment and co-responsibility between health professionals and the community. This strategy also intends to promote the development of actions from different sectors through partnerships, stimulating the recognition of health as a right, the organization of community and social control(17).

In addition, the Family Health Strategy has been considered a breakthrough in encouraging the achievement of health actions beyond the boundaries of health facilities; its purpose is not only to contribute to a greater involvement of health teams with the population, but also moves beyond biological action; it extends to social and human dimensions, as well ${ }^{(17,20)}$. The Family Health Strategy increases the operation of equity because it knows the population and it seeks to develop differentiated actions, aimed at real health needs ${ }^{(11,17)}$. Thus, equity enhances resolution in primary care.

\section{Conclusion}

The present study reveals a great strength of affiliation between mothers and the health facility to which they belong. Attributes such as accessibility (services utilization), longitudinality, coordination of attention, comprehensive care (services provided), and family and community orientation were considered strong by more than $80 \%$ of interviewees. Comprehensive care - available services - obtained the lowest score. 
The answers indicated that the FHU does not have the services to entirely care for the population; the most cited service was a vaccine room.

This study also identified the efforts of the FHU intended to approach the community and understand their real health needs, looking for ways to minimize problems and to promote qualified assistance to children. The PCATool-Brazil was adequate for this study, allowing the identification of the aspects of both the structure and the process of health service; it also provided a consistent evaluation of the FHU and the attributes related to the Family Health Strategy experienced by mothers of children under one year old.

We considered it extremely important to investigate child care in Family Health Units from the perspectives and experiences of mothers, in addition to assessing the assistance received by these children in health services, because it makes the identification of strengths and weakness possible and allows their maintenance or adjustment, if necessary, to improve child health services.

\section{References}

1. Ministério da Saúde (BR). Pacto nacional pela redução da mortalidade materna e neonatal. Informe da Atenção Básica 22, Ano 5, maio-junho; 2004. [acesso 16 jan 2012]. Disponível em: http://portal.saude.gov.br/ portal/arquivos/pdf/psfinfo_22.pdf

2. Ministério da Saúde (BR). Agenda de compromissos para a saúde integral da criança e redução da mortalidade infantil. Brasília (DF): Secretaria de Atenção à Saúde. Departamento de Ações Programáticas Estratégicas. Ministério da Saúde; 2004. [acesso 16 jan 2012]. Disponível em: http://bvsms.saude.gov.br/bvs/ publicacoes/agenda_compro_crianca.pdf

3. Roncalli AG, Lima KC. Impacto do Programa Saúde da Família sobre indicadores de saúde da criança em municípios de grande porte da região Nordestes do Brasil. Cienc Saúde Coletiva. [periódico na Internet]. 2006. [acesso 5 março 2012];11(3):713-24. Disponível em: http://dx.doi.org/10.1590/S1413-81232006000300018 4. Ribeiro JM, Siqueira SAV, Pinto LFS. Avaliação da atenção à saúde da criança (0-5 anos) no PSF de Teresópolis (RJ) segundo a percepção dos usuários. Cienc Saúde Coletiva. [periódico na Internet]. 2010. [acesso 5 março 2012];15(2):517-27. Disponível em: http://dx.doi.org/10.1590/S1413-81232010000200028 5. Ministério da Saúde (BR). Avaliação na atenção básica em saúde: caminhos da institucionalização. Brasília
(DF): Secretaria de Atenção à Saúde. Departamento de Atenção Básica. Coordenação de Acompanhamento e Avaliação; Ministério da Saúde; 2005.

6. Donabedian A. The quality of care - how come it be assessed? J. Am. Med. Assoc. 1988;260(12):1743-8.

7. Donabedian A. La calidad de la atención médica: definición y métodos de evaluación. México: Ediciones Científicas La Prensa Médica Mexicana; 1984.

8. Instituto Brasileiro de Geografia e Estatística. Censo 2010. Cidades. [acesso 16 jan 2012]. Disponível em: http://www.censo2010.ibge.gov.br/sinopse/index. php?uf $=35 \&$ dados $=1$

9. Secretaria Municipal da Saúde (SP). Floresce uma Vida. Ribeirão Preto (SP): Programa de Atenção Integral à Saúde da Criança e do Adolescente; 2010. 35 p. Relatório Anual. 10. Ministério da Saúde (BR). Manual do instrumento de avaliação da atenção primária à saúde: Primary Care Assessment Tool PCATool - Brasil. Brasília (DF): Secretaria de Atenção em Saúde. Departamento de Atenção Básica; Ministério da Saúde; 2010.

11. Starfield B. Atenção primária: equilíbrio entre necessidades de saúde, serviços e tecnologia. Brasília: UNESCO, Ministério da Saúde; 2002. 725 p.

12. Jesus WLA, Assis MMA. Revisão sistemática sobre o conceito de acesso nos serviços de saúde: contribuições do planejamento. Cienc Saúde Coletiva. [periódico na Internet]. 2010 [acesso 23 jan 2012];15(1):161-70. Disponível em: http://dx.doi.org/10.1590/S141381232010000100022

13. Ribeiro LCC, Rocha RL, Ramos-Jorge ML. Acolhimento às crianças na atenção primária à saúde: um estudo sobre a postura dos profissionais das equipes de saúde da família. Cad Saúde Pública. [periódico na Internet].2010. [acesso 23 jan 2012];26(12):231622. Disponível em: http://dx.doi.org/10.1590/S0102$311 \times 2010001200010$

14. Oliveira BRG, Collet N, Mello DF, Lima RAG. The therapeutic journey of families of children with respiratory diseases in the public health service. Rev. Latino-Am. Enfermagem. [periódico na Internet]. 2012 June [acesso 01 fev 2013] ; 20(3): 453-61. Disponível em: http://www. scielo.br/scielo.php?script=sci_arttext\&pid=S010411692012000300005\&lng=en. http://dx.doi. org/10.1590/S0104-11692012000300005.

15. Mello DF, Lima RAG, Scochi CGS. Health followup of children in poverty situation: between the routine and eventuality of daily care. Rev. Latino-Am. Enfermagem. [periódico na Internet]. 2007. [acesso 24 jan 2012];15(especial):820-7. Disponível em: http:// dx.doi.org/10.1590/S0104-11692007000700017 
16. Pinheiro R, Ferla A, Silva AG Júnior. Integrality in the population's health care programs. Cienc Saúde Coletiva. [periódico an Internet]. 2007. [acesso 1 fev 2012];12(2):343-9. Disponível em: http://dx.doi. org/10.1590/S1413-81232007000200010

17. Del Ciampo LA, Ricco RG, Daneluzzi JC, Del Ciampo IRL, Ferraz IS, Almeida CAN. O Programa de Saúde da Família e a Puericultura. Cienc Saúde Coletiva. [periódico na Internet]. 2006. [acesso 3 fev 2012];11(3):73943. Disponível em: http://dx.doi.org/10.1590/S141381232006000300021

18. Silva ACMA, Villar MAM, Cardoso MHCA. Perspectivas de médicos do Programa Saúde da Família acerca das linhas de cuidados propostas pela Agenda de Compromissos para a Saúde Integral da Criança e Redução da Mortalidade Infantil. Cad Saúde Pública. [periódico na Internet]. 2009. [acesso 6 fev 2012];25(2):349-58. Disponível em: http://dx.doi. org/10.1590/S0102-311X2009000200013

19. Pinto IC, Marciliano CSM, Zacharias FCM, Stina APN, Passeri IAG, Bulgarelli AF. Nursing care practices at an outpatient care center from an integrative perspective. Rev. Latino-Am. Enfermagem. [periódico na Internet]. 2012 Oct [acesso $01 \mathrm{fev}$ 2013]; 20(5):909-16. Disponível em: http://www. scielo.br/scielo.php?script=sci_arttext\&pid=S010411692012000500013\&lng=en. http://dx.doi. org/10.1590/S0104-11692012000500013.

20. Mercado F, Mercado M, Myers N, Hewit M, Haller NA. Patient preferences in choosing a primary care physicians. J Prim Care Community Health. 2012;3(2):125-31. doi: $10.1177 / 2150131911421802$. 